desde la academia

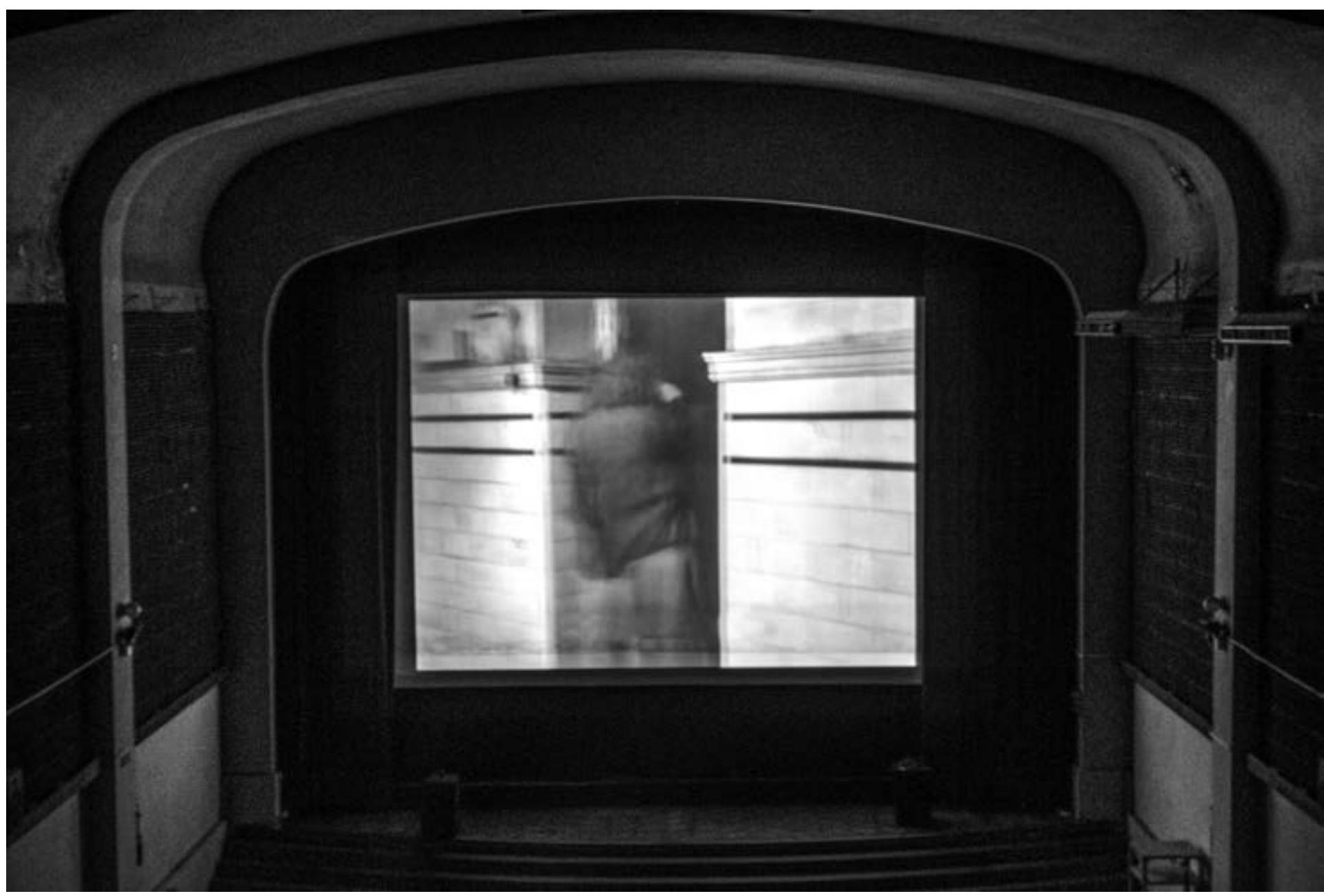

Foto: Cecilia Vidal

\title{
Una historia del cortometraje argentino desde los orígenes hasta la modernidad cinematográfica
}

A history of the Argentine short film from the origins to modern cinema

DOl: https://doi.org/10.22235/d.v0i27.1495

Javier Cossalter 


\section{RESUMEN}

El cortometraje como medio de expresión alternativo a la industria encontró su esplendor en Argentina durante la modernidad cinematográfica a través de la experimentación estética y la instrumentación política del medio. Sin embargo, el filme breve estuvo presente desde los inicios del cine. En este sentido, el artículo propone una historia del cortometraje nacional desde su conformación hasta la fase moderna, con el objetivo de relevar las diferentes modalidades y funciones que adquirió a lo largo del desarrollo del cine. De este modo se establecerán las vinculaciones y rupturas en las formas productivas y estéticas adoptadas por el cortometraje antes, durante y después del asentamiento del cine clásico-industrial.

Palabras clave: cine argentino, cortometraje, clasicismo, industria fílmica, modernidad cinematográfica.

\section{Introducción}

El filme de corta duración estuvo presente desde los comienzos del cinematógrafo, aunque la conciencia sobre el metraje arribó tiempo después. No obstante, hubo un período en la historia del cine mundial, y Argentina no fue la excepción, en donde el cortometraje se configuró como estandarte de renovación expresiva y semántica, y vehículo de transformación política: la modernidad cinematográfica, comprendida entre mediados de los años cincuenta y mediados de la década del setenta. En esta fase -ya centrándose exclusivamente en territorio argentino- el filme breve, situado casi por completo al margen de la industria del cine,${ }^{1}$ se convirtió no solo en un medio de formación y en una carta de presentación para los aspirantes a directores, sino también en un dispositivo de expresión, reflexión y acción. Las dos grandes premisas que caracterizaron al cortometraje en este período fueron la experimentación estética del lenguaje y una aproximación más auténtica a la realidad social. Esto fue posible gracias a una reconfiguración del campo cinematográfico que incluyó la creación de

\section{ABSTRACT}

The short film as a means of alternative expression to the industry found its splendor in Argentina during the period of modern cinema through aesthetic experimentation and the political instrumentation of the medium. However, the short film was present from the beginning of the cinema. In this sense, the present article proposes a history of the national short film from its conformation to the modern phase with the aim of revealing the different modalities and functions that acquired the short film during the development of the cinema. In this way, the linkages and ruptures will be established in the productive and aesthetic forms adopted by the short film before, during and after the settlement of classic-industrial cinema.

Keywords: Argentinean cinema, short film, tradition, filmic industry, modern cinema.

talleres y seminarios, la instauración de escuelas de cine, la fundación de la Asociación de Realizadores de Cortometraje, la entrada de corrientes fílmicas extranjeras y la paralización momentánea de la industria del cine. De este modo, entre 1958 y 1965 se desarrolló la fase de mayor visibilidad y constancia del corto local con un promedio de 34 producciones anuales. ${ }^{2}$ Así, el corto se constituyó en un pilar fundamental de la práctica fílmica alternativa al canon institucional durante la época del cine moderno. ${ }^{3}$

Ahora bien, el cortometraje como soporte de filmación no fue exclusivo de este período. Este artículo tiene como propósito revisar a grandes rasgos su historia desde sus comienzos hasta la etapa moderna, con el objetivo de indagar sobre las cualidades de las variantes que el corto articuló conforme al desarrollo de la cinematografía nacional. Ciertas expresiones fueron únicas y se desvanecieron en poco tiempo, algunas se afianzaron y continuaron a lo largo de la historia, otras se recuperaron tiempo después.
Javier Cossalter Consejo Nacional de Investigaciones Científicas y Tecnológicas. Universidad de Buenos Aires

Buenos Aires, Argentina javiercossalter@gmail.com

Recepción: 25/08/2017 Aceptación: 13/10/2017

1:: En las décadas del treinta y del cuarenta se produjo el auge del cine clásicoindustrial nacional. Este respondia a los cánones tradicionales tomados del cine norteamericano hollywoodense, que mantenía un triángulo que alimentaba el rédito económico: el sistema de estudios, estrellas y géneros.

2:: Dentro del macroperíodo de desarrollo del

cortometraje moderno se puede señalar también una primera etapa de gestación del campo del corto, con algunas manifestaciones esporádicas (1950-1957) y una tercera de radicalización política y estética del filme breve (1966/68-1976).

3:: El cortometraje moderno como objeto de estudio fue abordado por el autor en su tesis doctoral, defendida en la Universidad de Buenos Aires en 2016, y en diversas publicaciones académicas. Véase: Cossalter (2014, 2015a, 2015b). 
4:: En este trabajo se sigue la nomenclatura propuesta por José Vicente Benet (2008), quien utiliza el concepto de "modelo cinematográfico" para referirse a la ficción, el documental, la animación y el cine experimental como categorias o tipologías filmicas tradicionales.

5:: Otro ejemplo, pero con fines disimiles, es el de Operaciones del

Doctor Posadas (Enrique Lepage y Cia, 1899-

1900), filmado también por Eugenio Py, donde se registraba la labor del cirujano Alejandro Posadas.

Aqui el cinematógrafo era concebido como una

herramienta didácticocientífica. Como expresa

Andrea Cuarterolo,

"Posadas había comenzado a vislumbrar el potencial de estas nuevas tecnologías en el ámbito de la educación" (2013, p. 128).
Se puede constatar a través de esas décadas dos grandes marcos dentro de los que se ubicó el cortometraje: uno institucional, industrial y masivo; otro alternativo, artesanal y marginal. Es posible argumentar que las incursiones tempranas no cuadran dentro del modelo industrial puesto que no se había gestado hasta el momento. Sin embargo, el anhelo comercial y popular ya estaba en el germen de estas producciones. En esos años, la hegemonía de la primera línea dejó muy poco espacio para la exploración de la segunda. Es posible afirmar que, si bien pueden encontrarse antecedentes de un cine moderno durante aquellos años, el corto acompañó más que nada las tendencias productivas y estéticas del canon dominante. El cortometraje como medio de expresión audiovisual alternativo se consolidaría con posterioridad al asentamiento y auge de la industria cinematográfica.

La pertinencia de este trabajo reside en la propuesta de emprender una relectura del cine argentino hasta mediados del siglo XX desde una perspectiva centrada en el filme de corta duración. Un dispositivo polifacético, que ha adoptado múltiples modalidades y funciones, pero que supo aprovechar su condición de marginalidad y explotar su potencial de forma sostenida recién durante el desarrollo de la modernidad cinematográfica. Este recorrido no pretende ser abarcador, por lo que la elección de focalizar en determinadas instancias responde a la intención de tomar ejemplos representativos en la forma breve de los grandes modelos cinematográficos: ficción, documental, experimental. ${ }^{4}$ Se procurará consignar en cada caso la eficacia o justificación en el uso de la medida de corta duración. Luego de repasar las primeras experiencias cinematográficas argentinas, se inspeccionará cómo los noticiarios y documentales institucionales de los años veinte y treinta, los filmes científicos de higiene, los cortos ficcionales de variedad musical, las incursiones vanguardistas del documental y el documental propagandístico de los años cincuenta se posicionaron en relación a la industria cinematográfica y su modelo estético-productivo.
La brevedad como limitación técnica.

Vistas, actualidades, filmes históricos

La bandera argentina (1897), filmada por el francés Eugenio Py para la Casa Lepage, dio inicio al cine local. Esta película inaugural, al igual que los primeros filmes de los hermanos Lumière, contenía tan solo diecisiete metros, equivalente a unos treinta segundos. Sin embargo, esto respondía a una exigencia técnica: las bobinas por aquel entonces eran cortas. El cine nació con una extensión breve, pero la denominación cortometraje tal y como se entiende hoy en día resulta equívoca en referencia a estas primeras realizaciones cinematográficas, puesto que aquella era la única medida posible.

Si bien se debe esperar hasta la aparición del primer filme de larga duración en la segunda década del siglo XX para hacer una distinción de metrajes, aquellas películas originales experimentaron particularidades $\mathrm{y}$ variantes, y sentaron las bases primigenias de futuras modalidades. Eugenio Py, con la colaboración comercial del austríaco Max Glücksmann, comenzó a filmar en la casa de artículos fotográficos de Henri Lepage numerosas vistas con un metraje similar al del primer filme nacional mencionado. Entre tantas, podemos rescatar Visita del Dr. Campos Salles a Buenos Aires (1900), que marcaría el antecedente inmediato del noticiario filmado. ${ }^{5}$

Este tipo de filmes ligados a lo informativo fue adquiriendo la forma de actualidades "que representan acontecimientos recientes de interés público - políticos, militares, sociales, culturales, deportivos, etc. - según una práctica análoga a la del periodismo gráfico" (Marrone y Moyano Walker, 2006, p. 18). Estas ya no contaban con un único plano como las vistas, sino que pasaban a formar parte de una secuencialidad: había una intención narrativa. A partir de 1913, la Casa Lepage empezó a proyectarlas semanalmente en los cines bajo el nombre de Actualidades argentinas. 
También podían reconstruirse, en aquellas, ciertos episodios de la realidad inmediata situándose en el borde entre lo documental y la ficción.

Las vistas respondían a un registro documental porque captaban la realidad tal cual se desarrollaba delante de la cámara. Es en 1909 que puede fecharse el comienzo del cine de ficción argentino con la realización de $L a$ revolución de mayo, del italiano Mario Gallo, primer rollo argumental nacional. ${ }^{6}$ Esta película de un acto, cuya duración es de cinco minutos, fue acompañada por una serie de filmes históricos del mismo realizador entre los que figuraban El fusilamiento de Dorrego y La creación del himno. Estos "estarán estéticamente influenciados con la puesta en escena del filme de arte francés: actores teatrales, planos abiertos, casi sin movimientos de cámara y un montaje que va uniendo sucesivos cuadros" (Mell, 2011, parr. 9). Fueron interpretados por actores teatrales reconocidos en el ámbito local: Blanca Podestá, Alberto Ballerini, Eliseo Gutiérrez, entre otros.

La creación del himno, también conocido como El himno nacional, fue protagonizado por Eliseo Gutiérrez y Federico López, un actor uruguayo. El filme, que apenas supera los tres minutos y medio de duración, se compone de tres cuadros enlazados por corte directo e intertítulos breves que describen la acción venidera. La primera escena está dedicada al debate por la elección del himno, la segunda a su escritura y la tercera a la interpretación. Los cuadros inicial y final revisten una clara similitud con las obras de Georges Méliès ya que, además del carácter teatral y recargado del vestuario y la escenografía, están conformados por planos amplios apoteóticos, con muchos personajes en escena. Asimismo, la gestualidad y la expresión corporal se caracterizan por la exageración y el grotesco. En cuanto a los procedimientos cinematográficos, el filme evidencia la elementalidad en el manejo del lenguaje, a través del uso de una cámara fija y encuadres que recortan las figuras humanas, que demuestran la ausencia de conciencia acerca del equilibrio compositivo que regirá más adelante en el cine clásico.

Este es un panorama muy general del cine de los primeros tiempos ${ }^{7}$ en términos de registro y utilización del metraje disponible. No obstante, en relación a este trabajo, el 14 de diciembre de 1914 marcaría un primer hito: el estreno de Amalia de Enrique García Velloso, el primer largometraje argentino. ${ }^{8}$ ¿Es a partir de esta fecha entonces que se puede hablar de corto y de largometraje? ¿El surgimiento de uno trae consigo necesariamente la conciencia sobre el otro? La respuesta no es tan clara. Se podría pensar que hasta tanto el largometraje de ficción no se haya institucionalizado como norma estándar, la distinción entre metrajes breves y metrajes largos no recogería mayor productividad, dado que es en ese momento que el filme corto, relegado a los márgenes, comienza a explotar sus potencialidades.

No obstante, mucho tiempo después, en el período de auge del cortometraje alternativo, la discusión acerca del valor como forma autónoma estaría a la orden del día. Las especificidades de ambos metrajes exceden el argumento físico. En este punto surge una discusión terminológica. Aquellos que entienden a la duración como única particularidad del cortometraje -determinación esencial- lo catalogan bajo la noción de formato, cuya definición remite exclusivamente a la cuestión del tamaño de la película. Por otro lado, también es común que el corto sea considerado un género. Sin embargo, nada tiene que ver una tipología normativa como el melodrama, la comedia, el western, con la heterogeneidad de estilos y las múltiples modalidades que puede presentar el filme breve. Al descartar las etiquetas que encierran al cortometraje en una formación fija, aquí se opta por catalogarlo como un medio de expresión audiovisual con caracteres singulares.
6:: Cabe señalar que el primer ensayo de cine argentino argumental se corresponde con el film de Eugenio Cardini, Escenas callejeras, del año 1902.

7:: Para conocer en profundidad el cine de estos primeros años se recomiendan las lecturas de: Cuarterolo (2013); España (1996); Marrone (2003); y Peña (2012).

8:: Algunos investigadores hacen alusión a Tierra baja (Mario Gallo, 1912) como el primer largometraje argentino. Sin embargo, al encontrarse perdido no es posible corroborar la verdadera extensión del film. 
9:: Esta fue coordinada en el año 2009 por Paula

Félix-Didier -directora del Museo del cine

Pablo Ducrós Hicken-

Fernando Martín Peña cofundador de la Filmoteca

Buenos Aires-, con la colaboración del Instituto

Nacional de Cine y Artes Audiovisuales (INCAA)

10:: Las empresas

de ambos se habian organizado de forma independiente sin recibir subsidios estatales.
La aparición del primer noticiario argentino a principios de 1920 le daría cierta entidad e identidad a la medida de corta duración. En la década siguiente, previo a la consolidación de la industria cinematográfica, el filme de variedad musical haría un uso particular de la brevedad. Dos ejemplos que, como se verá más adelante, no revestían ningún signo de marginalidad sino todo lo contrario.

Entre la información y la propaganda. Noticiarios y documentales institucionales En 1891, Max Glücksmann comenzó a trabajar en la Casa Lepage. Dos años más tarde fue nombrado gerente. Junto con Eugenio Py y el propio Lepage constituyeron un equipo técnico y comercial pionero en el cine argentino. Hacia 1908 Lepage le vendió la empresa a su colaborador austríaco, que la renombró primero como Casa Lepage, de Max Glücksmann, para luego llamarla Cinematografía Max Glücksmann. A partir de ese año, las Actualidades argentinas tomaron una frecuencia semanal y hay quienes les adjudican el carácter de noticiarios por su interés sobre acontecimientos políticos y públicos al estilo de la prensa gráfica.

Sin embargo, fue en 1920 cuando nació el primer noticiario argentino mediante la fundación de Film Revista Valle. En 1911, el técnico y productor italiano Federico Valle se radicó en Argentina y a partir de entonces realizó numerosos filmes de carácter documental. El informativo, exhibido con una periodicidad semanal, se mantuvo activo durante diez años y produjo 657 ediciones. Sus características se pueden observar en una entrega del año 1926 editada con el nombre de "Film Revista Valle I" dentro de la Colección Mosaico Criollo: primera antología de cine mudo argentino. ${ }^{9} \mathrm{El}$ noticiario, cuya duración es de doce minutos, exhibe imágenes de interés político y cultural, diferenciadas por títulos en placas negras que funcionan como separadores temáticos. Dentro de cada sección se incorporan intertítulos explicativos. Los tópicos son de lo más variados: deportes, finanzas, relaciones exteriores -la visita del ex canciller alemán Dr. Hans Luther-, turismo -turistas brasileños en el Delta-, la Sociedad Rural Argentina, cine y diplomacia. Se puede señalar que la secuencialidad de las actualidades es enriquecida por un montaje ágil y la presencia de diversos recursos técnicos como el leve movimiento de cámara, fundidos a negro o encadenados, primeros planos y apertura en iris. Es posible advertir en estos procedimientos una mayor elaboración de la puesta en escena que marcaría la transición hacia un modelo clásico.

Según Irene Marrone y Mercedes Moyano Walker (2006), el noticiario incluye una tendencia hacia lo espectacular y otra hacia la información. De acuerdo a la época, su duración era diversa e iba desde los cinco hasta alrededor de los diez minutos y era habitual omitir la fecha en que ocurrían los hechos para facilitar la reedición. El objeto de estos noticiarios consistía no tanto en eventos espontáneos e inesperados sino más bien en acontecimientos organizados. El ejemplo antes descripto cuadra a la perfección con estas cualidades.

Si bien Glücksmann y Valle ${ }^{10}$ fueron los pioneros de lo "noticiable", con el paso del tiempo nuevas productoras se abocaron al terreno del noticiario y cosecharon grandes éxitos: en 1937, Kurt Lowe fundó el Noticiario Emelco; un año más tarde Antonio Ángel Díaz hizo lo suyo con Sucesos Argentinos y entre 1948 y 1958 funcionó el Noticiario Bonaerense, órgano estatal creado por Domingo Mercante en la provincia de Buenos Aires.

Tanto Glücksmann como Valle -y luego las productoras privadas- no solo realizaban noticiarios sino también documentales institucionales. A propósito de estos, Andrea Cuarterolo comenta:

El documental institucional fue, durante el período silente, el género que abordó, con mayor continuidad, temáticas de contenido político y social. Estos films tuvieron su apogeo en la década 
de 1920, gracias a la primavera democrática de los sucesivos gobiernos radicales, y decayeron, hacia 1930, con el golpe de estado de Uriburu (citado en Lusnich y Piedras, 2009, p. 161).

Las instituciones como YPF (Yacimientos Petrolíferos Fiscales), la Sociedad Rural, la Federación Agraria -y también sectores políticos como el Yrigoyenismo o el Partido Socialista-, contrataban a empresas productoras como las de Valle para realizar filmes promocionales. En este sentido, Federico Valle fue uno de los máximos exponentes de esta modalidad. ${ }^{11}$

Esos documentales tenían una duración de entre diez y veinte minutos y su estructura difería de la de los noticiarios. Estaban abocados a un único tema y su contenido estaba orientado hacia la propaganda política y la publicidad de empresas privadas. Por tal motivo, sus temas no respondían a la realidad inmediata y actual. El montaje de imágenes dejaba entrever una doble enunciación: la de la empresa contratante y la del director-realizador. No obstante, sí compartían con los noticiarios la combinación de imágenes rodadas para la ocasión, imágenes de archivo y dramatizaciones, como también el uso de intertítulos explicativos. Por ejemplo, El azúcar (Federico Valle, 1926) es una coproducción entre Cinematografía Valle y la empresa Kodak centrada en los procedimientos y técnicas de elaboración del azúcar en Argentina y Estados Unidos. Este documental de nueve minutos presenta extensas placas con detallados intertítulos informativos e imágenes de los trabajadores y las maquinarias en pleno proceso productivo, a partir de una puesta en escena elaborada que incluye diversos emplazamientos de cámara.

La continuidad en la producción de noticiarios cinematográficos y documentales institucionales a lo largo de la historia del cine argentino determina la eficacia del cortometraje documental para fines informativos, publicitarios y propagandísticos.
El cine breve educativo. Los filmes

científicos e higienistas

La rama de la ciencia fue otra de las modalidades que adoptó el cine en su etapa temprana. Se ha hecho alusión en las notas de este artículo al filme Operaciones del Doctor Posadas (Enrique Lepage y Cía., 1899-1900), considerado como el primer ejemplo de un cine didáctico y científico que se extendió durante el cine silente y prosiguió en los años posteriores. Algunas de sus características eran compartidas con el resto de las vistas, actualidades y los documentales institucionales. En palabras de Andrea Cuarterolo:

Los primeros films científicos fueron mayoritariamente productos por encargo, que se rodaron en las mismas compañías productoras que por entonces estaban dando forma al incipiente cine nacional. Concebidas en el seno de la naciente industria fílmica local, estas películas pioneras estuvieron sujetas a algunas de las mismas estrategias formales, temáticas y de mercado del cine comercial (2015, p. 53).

Otros filmes de esta índole fueron Técnica general para las amputaciones cineplásticas, nuevo procedimiento del Dr. Guillermo Bosch Arana, realizado por la empresa F.I.F.A en los años veinte, Instituto Modelo de Clínica Médica (1922) confeccionado por el Establecimiento Cinematográfico Martínez y Gunche, y Operaciones del Instituto de Clínica Quirúrgica (Luis Scaglione, 1925), producido por Colón Film (Cuarterolo, 2015).

A comienzos de la década del veinte cobró relevancia una variante del cine científico de carácter educativo y divulgativo: el filme higienista. La mosca y sus peligros (Eduardo Martínez de La Pera y Ernesto Gunche, 1920) fue uno de los más conocidos, ${ }^{12}$ y formó parte de una serie de otras películas similares que realizó la empresa y que recurrió a la técnica de la fotomicrografía, que permitía ampliar la imagen de un microscopio. ${ }^{13}$
11:: Algunos de los títulos que filmó para la empresa YPF fueron: Norte argentino: Salta, Jujuy y parte de Tucumán; La región de los hielos eternos; Córdoba y sus sierras; Nahuel Huapí; Por tierras cuyanas; La Pampa generosa; Hacia el Iguazú; Buenos Aires, la magnífica; Por tierras de Santa Fe (Di Chiara, 1996).

$12::$ La sifilis y sus consecuencias (Mario Gallo, 1921), realizado por encargo del Ministerio de Guerra, es otro de los filmes de higiene y divulgación de la época, que se encuentra hoy perdido.

13:: La película "incluye varias tomas de este tipo que, mediante la utilización de viñetas circulares, simulan estar filmadas a través de la lente de un microscopio" (Cuarterolo, 2013, p. 67). 


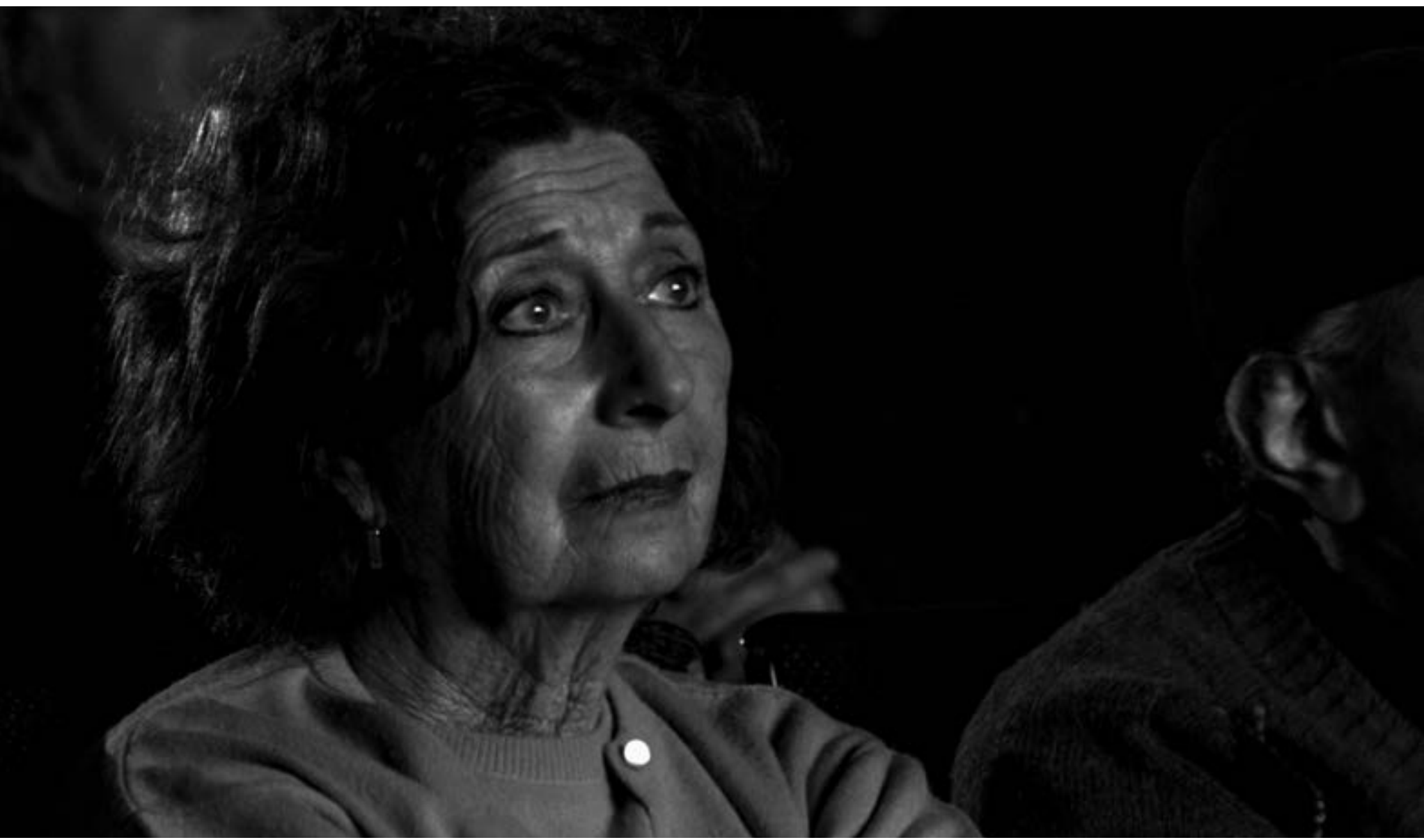

Esto se presentaba como una novedad que permitía promocionar el filme. Este mediometraje de 35 minutos está vertebrado por intertítulos que sostienen el anclaje científico. Sin embargo, desde su inicio plantea el propósito didáctico: "El objetivo principal de esta película es divulgar ante el público conocimientos que en general son solo de dominio de los investigadores". Los intertítulos explicativos acompañan las imágenes de un científico y su asistente que observan y analizan la morfología del insecto y sus partes a través de un microscopio. El registro visual ampliado de la mosca es intercalado entre los títulos informativos y la observación del método de investigación que llevan a cabo los especialistas. De a poco, el filme se enfoca en la capacidad de la mosca para hacer circular bacterias, desprenderse de los gérmenes y transmitir enfermedades entre los seres humanos.

De este modo, el discurso documental-científico de los intertítulos se vuelve sensacionalista -"si Ud. mata una mosca destruye Ud. veinte y dos billones de insectos peligrosos"-y las imágenes amplificadas del insecto adoptan un registro de tipo espectacular-fantástico que rozan lo monstruoso. Este mismo tono se advierte en el pasaje enfocado a la prevención, que muestra las consecuencias del contagio de enfermedades a través de imágenes de un niño con parálisis. La presentación y la forma de uso de diversos métodos para combatir a las moscas -cal, insecticidas, preparados caseros- completan este filme que tuvo un gran éxito educativo y comercial. Así, el discurso científico e higienista se articula con el elemento espectacular que enmarca a la función pedagógica y se convierte al mismo tiempo en un factor convocante.

Durante las primeras décadas de gestación del cine argentino, el cine científico se apoyó generalmente en la categoría documental -con algunas variantes-, y del mismo modo que el filme informativo y publicitario, la vertiente divulgativa estuvo anclada en la medida de corta y media duración. La rama del filme educativo - que posteriormente incluiría rubros como la sexualidad, la vialidad y la preservación ambiental, entre otros- pretende persuadir y generar un impacto inmediato en el destinatario. Por esa razón, estas películas de higiene social suelen organizarse en estructuras relativamente breves con el interés de no perder eficacia en su tarea de aprehensión del receptor. De hecho, en la actualidad y bajo el soporte televisivo, este género ha migrado al formato del anuncio que no supera el par de minutos. 
El antecesor del videoclip. El cortometraje musical

Como bien señala Claudio España (2000):

El sonido inauguró la industrialización y fue un factor convocante. El cine argentino comenzó a hablar para todos -nativos e inmigrantes para quienes la lectura de intertítulos o de subtítulos era una carga; alfabetos y analfabetos; gente de ciudad o de campo- (p. 28).

Muñequitas porteñas (José Agustín Ferreyra, 1931) fue el primer largometraje argentino completo con sonido en discos y ¡Tango! (Luis Moglia Barth, 1933), el primero con sonido óptico, sin discos. Sin embargo, la revolución sonora ya había llegado al cine argentino años atrás bajo el rubro de variedad musical en metraje breve.

En 1929, Alfredo Murúa se asoció a la productora Ariel de Roberto Guidi, y con la dirección de Eleuterio Iribarren produjeron el cortometraje Mosaico criollo mediante un sistema propio de sonorización en discos. Este, que era el primero de una pretendida serie, fue catalogado como "revista musical filmada" y titulado como Variedades sonoras. Es relevante articular, en torno al contenido y a la expresión, las diferentes denominaciones que adquirió: la noción de revista, la idea del mosaico y la etiqueta de variedades apuntan a la forma -la unión de pequeños elementos diversos-, mientras que la música y el criollismo responden al objeto-tema. Estos últimos serían centrales en los inicios de la industria cinematográfica argentina del período sonoro.

Mosaico criollo tiene una duración de nueve minutos y está dividido en cuatro escenas antecedidas por un rótulo a modo de título informativo. Aquí, a diferencia de los noticiarios cuyos bloques yuxtapuestos no tenían un nexo común, es la música el hilo vertebrador que atraviesa los fragmentos de los diferentes géneros populares que se presentan en pantalla: Joaquina Carreras canta Triste está mi rancho; Giménez y Suárez ejecutan un malambo; Julio Perceval realiza un solo de piano, y Anita Palmero canta el tango Botarate. En cuanto a su estructura, se puede comentar algunas cuestiones. En primer lugar, la brevedad está determinada por el género musical: la duración de los temas no excede los pocos minutos. En segundo lugar, en los cuatro ejemplos se observa un emplazamiento de cámara frontal, plano fijo - sin movimiento de cámara, salvo el mínimo movimiento de reencuadre en la última escena-, y la figura protagónica que se ubica en el centro del cuadro, un rasgo que sería primordial en la narración clásica.

En relación al tamaño del plano, bien podría responder a un plano medio largo que recorta la figura humana por debajo de las rodillas. Esta tipología se centra en las posibilidades expresivas del actor -en este caso, músicos, cantantes y bailarines - pero mantiene al mismo tiempo una relación con el ambiente. Por último, se destaca una mayor intención estética en el cuadro del malambo, que además de intercalar intertítulos descriptivos, pone en juego dos tamaños de plano diferentes: un plano medio corto y un plano medio largo. Esto se debe a la merecida atención a los pies en el zapateo. Sin embargo, en el plano medio largo las cabezas de los bailarines resultan cortadas, lo que demuestra un manejo todavía rudimentario del lenguaje fílmico. En definitiva, se pueden observar en este filme marcas de transición entre el cine silente y el cine sonoro clásico: rótulos intercalados, cuadros cuasi autónomos y la presencia mínima del montaje, además de la frontalidad, el centrado, el equilibrio del cuadro y la jerarquización del musical como elemento distintivo del cine argentino que se asienta en el cortometraje como medida eficaz.

En 1927 ingresó a la Argentina el sistema Phonofilm De Forest. "El problema con el De Forest era que solo podía utilizar rollos pequeños, por lo que era apto únicamente para cortometrajes. Es por esta razón que se lo usaba para noticieros o cortos musicales", 
14:: El artículo de Muoyo, "Gardel y el cine. La otra dimensión del mito", fue publicado en el año 2000 en la revista digital Tuxys: Arte y cultura. El artículo ya no está disponible en línea, pero su autor tuvo la gentileza de facilitar

el texto original para la realización de este trabajo. destaca Adrián Muoyo ${ }^{14}$. Por esta razón, el sonido óptico tendría que esperar unos años más para desembarcar en el largometraje. Poco tiempo después de su llegada, Cinematografía Valle adquirió este sistema de sonido y fue el propio Valle quien contrató a Eduardo Morera para que dirigiera unos cortos musicales. Carlos Gardel fue el primer artista en ser convocado. En palabras de Muoyo:

Entre octubre y noviembre de 1930 se realizaron los quince cortos que contenían temas cantados por Gardel [...] Debido a que se trabajaba con grabación de sonido directo se tomaron algunas precauciones para asegurar el aislamiento sonoro, aunque las soluciones elegidas fueron bastante primitivas [...] La precariedad de la producción también afectó el proceso de revelado, donde se perdieron cuatro cortos.

Los once cortos que se conservan y que fueron estrenados en el Cine Astral en mayo de 1931 son: Viejo smoking, Rosas de otoño, Yira yira, Mano a Mano, Tengo miedo, Añoranzas, Canchero, Enfundá la mandolina, Padrino Pelao, El carretero y El quinielero. Como en el ejemplo antes comentado, aquí la brevedad está dada por el tema musical que no sobrepasa el par de minutos. En muchos de estos cortos la interpretación musical está precedida por una introducción o situación algo teatral, que se presenta como novedosa y que incluye algunos de los caracteres del cine clásico. No obstante, el segmento destinado al cuadro musical reviste, en casi todos los casos, la misma simplicidad narrativa señalada en Mosaico criollo.

En Mano a mano (música de Carlos Gardel y José Razzano, y letra de Celedonio Esteban Flores) Gardel y Flores mantienen un diálogo en el que intercambian elogios por haber participado juntos de este tango. Los dos hombres se acercan hacia el centro de un escenario y luego de la breve charla hay un corte directo a la interpretación: Gardel en plano medio cercano canta y toca la guitarra, mientras que en segundo plano -difuminado- lo secundan dos músicos. La misma modalidad se produce en El carretero (música y letra de Arturo de Nava) y en Yira yira (música y letra de Enrique Santos Discépolo), con la presencia de Arturo de Nava y Enrique Santos Discépolo, respectivamente. En el primero, también los dos artistas se agradecen y es sugestivo el modo en que concluye el intercambio, ya que ambos miran hacia la cámara y Gardel anuncia: "Y que el público juzgue”. Resulta interesante esta interpelación directa a la audiencia. Luego la canción se desarrolla de igual forma que la anterior. En Yira yira, Gardel le pregunta al creador del tango qué ha querido hacer con él y terminan la charla con una humorada.

En Rosas de otoño (música de Guillermo Barbieri y letra de José Rial) Gardel dialoga con el director de orquesta Francisco Canaro. Ambos entran al escenario por los laterales opuestos y se encuentran en el centro. El cantante habla hacia al frente y hace una particular defensa de la música y del cine local: "Como siempre, hermano, dispuesto a defender nuestro idioma, nuestras costumbres y nuestras canciones con la ayuda del film sonoro argentino". Junto con la centralidad de la figura humana, la frontalidad se convirtió en un estandarte de la narración clásica, pero no así la interpelación directa al espectador que ponía en evidencia el artificio, reservada solo para algunos géneros.

Otros cortos como Padrino Pelao (música y letra de Enrique Delfino), Tengo miedo (música de José María Aguilar y letra de Celedonio Esteban Flores), Añoranzas (música y letra de José María Aguilar) y Canchero (música de Arturo de Bassi y letra de Celedonio Esteban Flores), cuentan solo con la interpretación a cargo de Gardel y su guitarra, o acompañado de sus músicos en un escenario con telón negro.

El más sofisticado de todos los cortos es Viejo smoking (música de José María Aguilar y letra de Celedonio 
Esteban Flores). Se trata de una pequeña escena dramática con gags cómicos que sirven como disparador del tango, cuya interpretación es incorporada esta vez al mismo espacio escénico. La hija de la dueña de la pensión donde vive el personaje de Gardel - una joven gallega (Inés Murray) - llega para reclamarle los alquileres adeudados, pero este no encuentra forma de pagarle. Luego aparece en escena su amigo (César Fiaschi) y le propone vender el smoking que tiene guardado para subsanar su situación económica. La negación de Gardel y su nostalgia por el viejo smoking da pie a la interpretación que es precedida por la recitación a capela de algunos de sus versos, gesto concebido como elemento de transición y continuidad que suaviza el pasaje del núcleo narrativo al cuadro musical puro. La situación está trabajada a partir de pocos emplazamientos diferentes de cámara e intercala planos de conjunto y planos medios largos y cercanos. Hay también una clara puesta en escena en torno al decorado y al vestuario que demuestra un proyecto más elaborado del cine como espectáculo y hecho estético. Los protagonistas siempre se ubican en el centro del cuadro, rasgo que se mantendrá como una constante distintiva del modelo clásico.

Tanto Mosaico criollo como los cortos de Gardel experimentaron cierta conciencia sobre el metraje, aunque todavía estaban determinados por algunas exigencias técnicas. La corta duración del tema musical se adaptaba a la perfección a la medida breve. La articulación de la imagen del intérprete en sincronía con un tema musical completo anticipó, de forma embrionaria, la modalidad del videoclip que se popularizó en televisión en los años ochenta. Si bien el musical como tópico y forma expresiva luego tendrá su desarrollo en las ficciones narrativas de largometraje, el momento concreto de la música -que incluye la voz, el acompañamiento y en algunos casos el baile- seguirá comportándose como un cuadro musical de breve duración, para reforzar así la eficacia estructural de esa medida con los parámetros estéticos y narrativos de esta variante fílmica. En cuanto a su factura estética y su intención comercial, a pesar de las deficiencias en términos de sincronización y ciertas marcas rudimentarias en la puesta de cámara, los procedimientos y recursos analizados en estas ficciones musicales dan cuenta de su incipiente pero pretendida y efectiva inserción en el modelo del cine clásico-industrial ya constituido en Estados Unidos y en plena gestación en el ámbito cinematográfico argentino.

\section{Cine de vanguardia independiente.}

Experimentación en el cortometraje documental Mientras que los noticiarios y documentales institucionales por encargo y las variedades musicales anticipaban, prefiguraban y acompañaban los preceptos del cine industrial -producido al interior de grandes empresas que apuntaban al éxito comercial de sus realizaciones destinadas a un público masivo-, se puede encontrar en esta etapa algún destello de cine vanguardista ajeno al rédito económico. ${ }^{15}$ Andrea Cuarterolo (2013) explica a la perfección el porqué del rápido abandono de esta renovación no solo del lenguaje cinematográfico sino de toda una concepción del séptimo arte que sería retomada en la modernización de los años sesenta:

En la Argentina, como en la mayor parte de Latinoamérica, las influencias de las vanguardias no llegaron ni a la fotografía ni al cine sino hasta la década de 1930, y lo hicieron por lo general en forma breve y dispersa. En el cine especialmente, ese proceso de experimentación formal se vio casi inmediatamente interrumpido por la llegada del sonido, que inició una acelerada etapa de industrialización regida cada vez más por imperativas de mercado y políticas populistas (p. 230).

Si bien la influencia de Hollywood era avasalladora, a fines de los años veinte comenzaron a abrirse pequeños reductos de circulación de un cine alternativo. En 1927, el crítico de cine y jazz León Klimovsky organizó en
15:: Por cine de vanguardia se entiende a las tendencias filmicas europeas acaecidas en los años diez y veinte del siglo XX, en correlato con el desarrollo de las vanguardias históricas. El impresionismo francés, el cine expresionista alemán, el cine históricomaterialista soviético y el surrealismo, entre otros, se caracterizaron por el distanciamiento del aspecto comercial del arte y la ruptura con las convenciones narrativas tradicionales. 
16:: Para conocer en profundidad la relación de la fotografía y el cine en Horacio Coppola y la obra fílmica de su estadia en Europa, véase: Cuarterolo (2013) Capítulo V: Con la mirada en Europa. Modernidad y tradición en la obra de Horacio Coppola-; y

Oubiña (2009).

17:: Coppola filmaria dos cortometrajes más

en Argentina para la Dirección de Maternidad e Infancia: Vestir al bebé (1937) y Do de pecho (1943). Estos filmes de encargo responden al rubro institucional por lo que quedan afuera de la consideración en este apartado puntual.
Buenos Aires la primera exhibición de cine arte, que convocó a algunos de los artistas e intelectuales más destacados del momento como Romero Brest, Horacio Cóppola, Jorge Luis Borges y José Luis Romero, entre otros. Al año siguiente se conformaría el primer club de cine del país: el Cine Club de Buenos Aires.

Existen dudas acerca de si ese mismo año iniciaron las proyecciones orgánicas, pero lo cierto es que entre el 21 de agosto de 1929 y el 28 de octubre de 1931 el Cine Club de Buenos Aires exhibió de forma regular filmes de los cómicos del período mudo, cine clásico norteamericano y trabajos de la vanguardia francesa, alemana y soviética.

Sin embargo, la importación y exhibición de películas foráneas ajenas a la explotación comercial no fue su único objetivo. En su acta fundacional figuraba también el dictado de conferencias para orientar al espectador, la fundación de una revista y la organización de una biblioteca y una cinemateca. La entidad también se orientaría hacia la realización de filmes propios, motivo por el que decidieron clausurar la revisión de filmes en 1931. Si bien esos ensayos cinematográficos no dejaron huella alguna, fue Horacio Coppola quien, por fuera del cineclub y de forma artesanal e independiente, se dedicó a la realización en el exterior y dentro del país.

Fotógrafo desde finales de los años veinte, Coppola ${ }^{16}$ viajó a Europa y filmó, influido por el lenguaje del cine vanguardista que había experimentado en el cineclub y motivado por el aprendizaje que estaba adquiriendo en el viejo continente, tres cortometrajes entre 1930 y 1935: uno en Berlín, otro en París y el tercero en Londres. En su regreso a la Argentina filmó su cuarto cortometraje: Asi nació el obelisco (1936). ${ }^{17}$ Cabe destacar la elección del modelo cinematográfico para encarar estos cortos, ya que Coppola comenzó con el cine experimental para asentarse luego en la vertiente documental. Como en gran parte de ese cine de vanguardia, más alejado de la veta narrativa, en esta ocasión el cortometraje también sería el medio escogido para explorar el lenguaje y desarrollar un cine ensayístico, poético y perceptivo. El cine experimental propone mecanismos perceptivos diferentes respecto de aquellos que componen la percepción habitual del ojo normal. En este sentido, la condensación del tiempo y la intensidad que adquieren los elementos significantes plasmados gracias a la breve duración convierten al cortometraje en un vehículo privilegiado para desarrollar la ruptura de los aspectos perceptivos tradicionales, que convocan al receptor a disponerse de forma activa.

Traum (1933) -cuya traducción al español significa "sueño"- es un ensayo poético-psicológico que recobra el cine surrealista de Luis Buñuel, Germaine Dulac y René Clair. Allí están presentes lo onírico, la metáfora, la animación de objetos inanimados y la yuxtaposición de incongruencias. En sus siguientes dos trabajos, Coppola se apartó de la subjetividad experimental para centrarse en el motivo de la ciudad. En Un muelle del Sena (Un Quai de la Seine, 1934), planos cortos y descriptivos, fragmentarios, en picado -extremo en algunas oportunidades- registran a modo de postales distintos componentes de la urbe. En Un domingo en Hampstead Heath (A Sunday in Hampstead Heath, 1935) retoma el motivo urbano. Los planos generales y planos cortos se intercalan con paneos, picados y cámara baja, y los personajes de la ciudad son capturados cual retrato fotográfico, dándole al montaje y a la cámara un rol protagónico. Como bien señala Oubiña (2009): “tanto en Un muelle del Sena como en Un domingo en Hampstead Heath, Coppola describe el transcurso del tiempo" (p. 7). Para ello, el montaje y el movimiento autónomo de la cámara resultan esenciales.

Este modo de utilizar el montaje, la cámara y el encuadre fue recuperado por Coppola en Asi nació el obelisco, su único corto de autor en Argentina. Su factura artesanal e independiente puede observarse desde el inicio a través de los créditos realizados a 
mano. El fotógrafo argentino filmó el proceso de construcción del obelisco con el estilo emprendido en los filmes urbanos europeos. La inmovilidad del edificio se contrapone con la movilidad de la cámara que no solo se aboca al objeto central, sino que observa de reojo a su alrededor. Los planos picados exhiben su monumentalidad y los contrapicados desde el interior y en las alturas ostentan otra grandeza: la de la ciudad. Planos cerrados, cercanos y fragmentarios muestran en detalle la labor de los obreros, los materiales y los instrumentos de trabajo. Estos planos cortos, casi inmóviles, puestos en sucesión por un montaje dinámico, directo y continuo, se intercalan con imágenes donde la cámara practica movimientos verticales y horizontales que nos ofrecen una mirada sobre la estructura material y otra en torno a la estructura urbana.

La audacia formal de ciertos planos resulta impensada para aquellos años: el cuadro se divide por medio de la geometría del edificio en construcción, y gracias al empleo de la profundidad de campo se aprecia en un primer plano las vigas, los tornillos y los alambres, mientras que en un segundo plano aparecen los edificios, los automóviles y las personas. El summum de la experimentación con el lenguaje se completa en la secuencia del montacargas: la cámara realiza un desplazamiento por el interior de la estructura desde la oscuridad del suelo hasta la luminosidad del cielo, para luego, desde lo más alto, contemplar otra vez la ciudad. La libertad estética de esta producción independiente, que deriva de la ausencia de trabas comerciales, se refleja en la exploración de un abanico de operaciones de lenguaje, sustentada en la amplitud formal ofrecida por la estructura dinámica de la medida breve.

De un modo similar, se puede encontrar antecedentes vanguardistas en el cortometraje al interior del Cine Club Argentino fundado en 1932. Alli participaron en sus inicios Carlos Connio Santini, Jorge Méndez Delfıno, Carlos Laurenz, Enrique de la Cárcova y Ho- racio Gutiérrez Larreta. Ajena a los objetivos de lucro, entre las décadas de 1930 y 1950 la institución realizó más de cincuenta concursos y concretó innumerables filmes amateurs en $16 \mathrm{~mm}$, entre ellos cortometrajes documentales que experimentaban con los recursos del lenguaje fílmico. Algunos ejemplos son Caperucita roja (Méndez Delfino, 1933), Nahuel Huapi y su región (Emilio Werner, 1937) y Luz y sombra (Enrique de la Cárcova, 1937), entre otros. Sin embargo, la falta de acceso a los textos fílmicos impide realizar un abordaje analítico serio y justificado. ${ }^{18}$

Uno de los pocos cortos conservados es La gesta inmortal (Roberto Robertié y Carlos Barrios Barón, 1950), obra ganadora del primer premio en la categoría de Películas Documentales del Cine Club Argentino. Este corto documental homenajea a José de San Martín a través de imágenes de las estatuas y bajorrelieves que conforman su monumento. La construcción innovadora del relato se sostiene en la conjunción de tres elementos: el movimiento autónomo de la cámara, el uso marcado del montaje y el trabajo de fotografía. Al principio la cámara recorre las figuras, que se suceden articuladas por un leve fundido. Luego, esta cámara expeditiva -que incluye movimientos giratorios- se combina con un montaje corto y directo sobre planos cerrados, difuminados y en penumbra con el fin de focalizar elementos puntuales de los bajorrelieves, acompañado por el sonido de trompetas, galope de caballos y arengas pronunciadas por voces anónimas. El relato cierra con una imagen en contraluz que magnifica al monumento central. De este modo se edifica una narración audiovisual sobre materialidades inmóviles gracias a procedimientos básicos de la gramática fílmica que evidencian las huellas subjetivas de la enunciación. Como en el ejemplo anterior, la experimentación formal coloca el acento en el carácter plástico de la imagen por sobre el aspecto narrativo, un desarrollo perceptual que encuentra una eficacia mayor en el marco de la brevedad.
18:: A lo largo del proceso de la investigación se han recorrido archivos e instituciones, pero no se han podido encontrar dichos filmes de cortometraje. 
19:: Para un estudio profundo sobre el noticiario y el documental oficial en este período se recomienda consultar la obra de Marrone y Moyano Walker (2006).

20:: En términos de Bill Nichols la denominada voz de Dios responde a un "tipo de documental [que] se dirige directamente al espectador con una voz desencarnada, exterior al mundo representado en el documental y llena de autoridad epistémica [...] Se caracteriza por emplear una retórica persuasiva que le permite establecer juicios

'bien fundados' sobre la realidad que presenta" (Weinrichter, 2004, p. 36).
Se podría aseverar que este uso del montaje rítmico, propio de la vanguardia, y la presencia de una cámara dinámica, presente en los dos cortos analizados, serán rasgos y recursos que la modernidad de los años sesenta retomará y explotará al máximo, y que encontrarán en las potencialidades estructurales y estéticas del cortometraje un espacio para desenvolverse con libertad y creatividad. En lo que respecta al documental y su experimentación con el lenguaje, en este cine independiente y amateur se puede encontrar uno de los precedentes más directos del cortometraje moderno.

El corto como propaganda política.

El documental institucional

durante el peronismo

Desde el inicio de la presidencia de Juan Domingo Perón en junio de 1946, el gobierno promovió un programa económico anclado en dos premisas: la puesta en marcha de un impulso industrialista y una fuerte presencia del Estado como productor. Para ello, fue clave la sustitución de importaciones por producción de índole nacional a través de una política crediticia y una protección cambiaria. La industria cinematográfica argentina resultó beneficiada por esta política proteccionista ya que, en palabras de Clara Kriger (2009) "se vio favorecida por la inyección de dinero proveniente del aumento del gasto público [...] y por la restricción de la exhibición de films extranjeros" (p. 42). El gobierno brindó créditos blandos a largo plazo para la producción y estableció la obligatoriedad de exhibición de filmes nacionales ${ }^{19}$.

Para 1943, la creación de la Subsecretaría de Informaciones y Prensa -destinada a regular las relaciones entre el Estado y los medios masivos- anticipaba el fuerte sesgo intervencionista que el Estado adoptaría luego en materia de comunicaciones. Ese mismo año se dictó el decreto $\mathrm{N}^{\circ}$ 18.405 para el fomento de los noticiarios en la Argentina y su exhibición obligatoria en todas las salas. Su contenido sería la propaganda nacional. A partir de entonces, tanto los noticiarios como el cine documental adquirieron una explícita impronta pedagógica y didáctica (Kriger, 2009).
Como ya se mencionó, existían intercambios, pero también diferencias entre el noticiario y el documental. Ambos se ubicaban dentro de la categoría documental y el segundo tomaba extractos del primero. Sin embargo, diferían en la extensión de la película y en la unidad y profundidad del tema abordado: los documentales oscilaban entre los diez y los veinte minutos y estaban abocados a un único tema. La mayor parte de los documentales de esta etapa eran elaborados por las mismas productoras privadas que realizaban los noticiarios. Como bien señalan Marrone y Moyano Walker (2006):

Dichos documentales [...] comparten con el noticiario el tipo de producción industrial debido a su carácter seriado, anónimo y a su formato estándar, así como su alcance masivo, ya que su exhibición se lleva a cabo en las salas cinematográficas (p. 27).

Algunos de ellos portaban la firma del realizador, como el caso de Su obra de amor (Argentina Sono Film, 1953) de Carlos Borcosque. Otros solo indicaban el sello productor-ejemplos como Rumbo a la Argentina (Emelco, 1948) y Para todos los hombres del mundo (Noticiero Bonaerense, Emelco y Sucesos Argentinos, 1949)-. Estas obras eran favorecidas por todas aquellas estrategias de protección que el gobierno promovía para beneficiar al cine nacional.

En cuanto a la modalidad del relato, esta se encuentra muy ligada a los objetivos perseguidos. Kriger (2009) diferencia a los documentales tradicionales de los docudramas, y dentro de la primera vertiente señala a los que "documentan las obras realizadas, ya sea por instituciones estatales o paraestatales, como resultado de las políticas de estado del período" (p. 113), y a los que intentan difundir diferentes aspectos del Partido Peronista. En relación a su estructura, esta "se cimienta sobre la dicotomía que enfrentaba el 'antes', ligado a los males del antiguo régimen, al 'ahora', relacionado con lo que la Subsecretaría presenta como las soluciones de los viejos 
males, generadas por el gobierno justicialista y orientadas a construir la Nueva Argentina” (p. 119). En otras palabras, se revela un presente que asegura una sociedad armónica y orgánica, y que procura construir, a través de las obras del nuevo gobierno, una identidad nacional y perdurable. Para ello, el filme recurre a una voz en over $^{20}$ que instala un discurso que se pretende objetivo, que no da lugar a la contradicción y funda su autoridad en la palabra, la imagen y las obras de Perón (Cossalter, 2013). La narración se apoya en las instituciones de gobierno y en la figura presidencial, elementos que legitiman la realidad conciliada que el filme propaga. A su vez, dichos documentales tienden a ocultar las huellas de la enunciación con el interés de construir un discurso cerrado, hegemónico, efectivo y sin fracturas.

Su obra de amor conjuga el accionar político de Eva Perón con la difusión de las obras realizadas por la fundación que lleva su nombre. El documental se sustenta en una entidad y en una figura del gobierno. Una voz en over, informativa y persuasiva, guía el relato, conformado por una estructura clásica compuesta de doce secuencias demarcadas por un signo de puntuación. En este caso, la dicotomía entre pasado y presente se evidencia en un desarrollo que ocupa tanto la banda de imagen como la banda de sonido. Las imágenes de niños en el campo sin medios de transporte para concurrir a las escuelas y otros hacinados en los asilos, son acompañadas por una narración que afırma que Eva miraba "la injusticia social que había imperado hasta entonces". No obstante, a partir de la creación de la Fundación de Ayuda Social, a ningún niño le faltó una cama ni un médico, según expresa la voz. También repara en los trenes sanitarios que llegan a los lugares más recónditos del país con el propósito de que, según la narración, "nadie se sienta olvidado". En este sentido, estamos frente a una identidad nacional -en tanto igualdad abarcadora- que intenta homogeneizar a la sociedad y que se manifiesta como un valor primordial de la vida social. De este modo se construye un universo armónico, estable y sin fracturas.

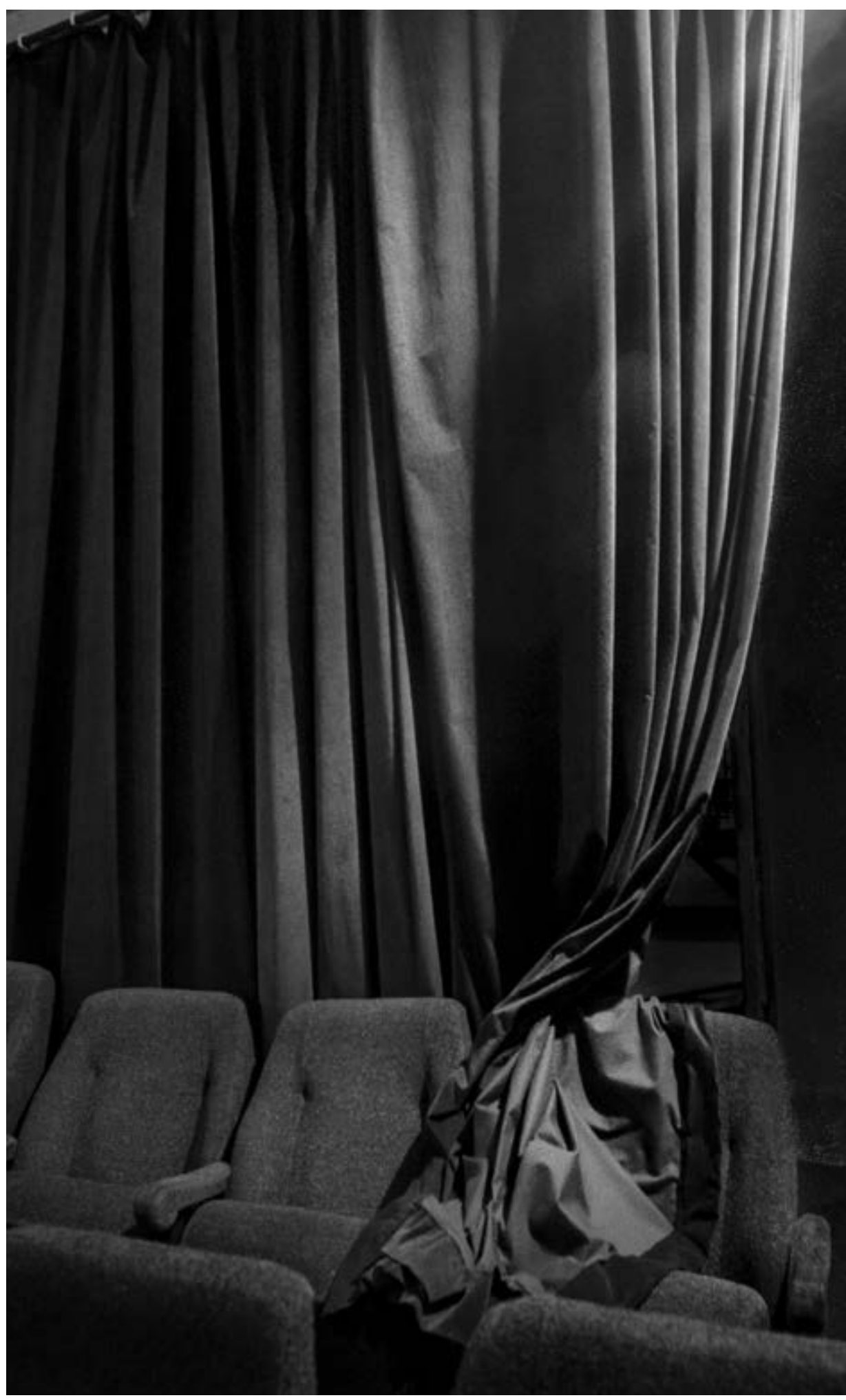

Foto: Cecilia Vidal 
Otra de las contribuciones que hizo Eva para alcanzar dicho pretendido estado de situación fue la creación de la Ciudad Infantil. Mientras se observan imágenes de niños felices jugando, la voz narradora expone los problemas del pasado: "Los niños pobres eran en aquel momento los desheredados de la suerte y la fortuna. No sabían de sonrisa, de ternura, ni del placer de un juguete". Acto seguido, un montaje en contrapunto enseña fotogramas de niños mal vestidos, cabizbajos, frente a otros contentos y con guardapolvos resplandecientes. La importancia colocada en la entidad gubernamental se complementa con la presencia de Perón y Eva junto a los niños como un gesto de legitimación de las acciones.

En Rumbo a la Argentina la división entre el antes y el ahora se reconfigura bajo otra modalidad que pareciera portar una significación semejante: allá, Europa, el mundo destrozado y debilitado por la guerra; acá, Argentina, un lugar consolidado, afianzado y en ascenso. El documental se inicia con una leyenda que, en un fragmento, dice: "para todos los hombres del mundo que quieran habitar el suelo argentino", seguido de las imágenes de Perón en el Congreso de la Nación durante el acto de lanzamiento de la política inmigratoria del Primer Plan Quinquenal. $\mathrm{Al}$ igual que en el ejemplo anterior, se cuenta aquí con la figura presidencial y la difusión de una obra de gobierno. También se procura pregonar la noción de una nación inclusiva que ofrece grandes posibilidades de trabajo a través del "convenio inmigratorio entre Argentina e Italia”. Una vez más, es la voz en over la que oficia como guía rectora del relato y que contrasta con insistencia la debacle del viejo mundo contra la firmeza y la estabilidad local. En su alocución se puede apreciar la premisa de la identidad sólida de una nación que prospera y en donde los trabajadores se encuentran complacidos y arraigados. Esta idea también se sostiene y se refuerza desde la banda visual. Las imágenes de inmigrantes abatidos y desganados en parajes decadentes asisten a la voz narradora que afirma: "la Europa destrozada no les da oportunidad de reconstruir el hogar [...] y soñar con un mundo de paz".
De inmediato se los exhibe en tierra argentina, acoplados a una sociedad nueva que, como bien enuncia la voz, anhela "poblar al país de habitantes fuertes, dignos de mezclar su sangre en el magnífico crisol de nuestra raza”.

En el caso de Para todos los hombres del mundo, comienza con una voz en over que asevera: "para todos los hombres del mundo que llegan a nuestra tierra, la institución que asegura el bienestar de todos los trabajadores del país que vengan de donde vinieran es la Secretaría de Trabajo y Previsión”. Una vez más, desde el comienzo se legitima, a través del Estado y por medio de esta voz desencarnada, una acción gubernamental, en este caso otra vez acerca de la política inmigratoria. Esta se concibe como convocante y aglutinadora, destinada a todas las razas, en sintonía con aquella identidad homogénea e inclusiva ya planteada. La transparencia enunciativa del relato que se apoya en la voz narradora despersonalizada y en un montaje que esconde las huellas del meganarrador, se corrobora en el cierre del documental, que finaliza con el flamear de la bandera argentina. De esta forma se clausura el discurso al incorporar un símbolo patrio local con el propósito de inmiscuir las obras de gobierno dentro de una identidad nacional que excede a la política partidaria.

Esos objetivos de propaganda política se dieron de manera efectiva gracias a la conjunción del documental con las potencialidades estructurales del cortometraje. La breve duración del relato, abocado de forma orgánica a un solo tema, permite condensar la acción e imprimirle una intensidad mayor. En correlato con esta disposición, la concentración temática y narrativa posibilita construir una relación inmediata y eficaz con el receptor, que toma una posición absorta. Así se logra incidir en él mediante la perspectiva de una identidad conciliadora, equilibrada, integral y solidaria. En contraposición, un relato de larga duración que por lo general tiende a distender la acción y complejizar la trama a partir de líneas narrativas secundarias, perdería eficiencia a la hora de impactar de forma clara, concisa y directa en el destinatario. 


\section{Reflexiones finales}

Este artículo ha pretendido realizar una historización del cortometraje en Argentina desde sus inicios hasta el cine moderno, momento en el que se convirtió en el sostén de la renovación cinematográfica y en el posterior vehículo de transformación política. El cine nació breve porque era el único metraje disponible, y aquellas primeras vistas fueron de carácter documental. En este sentido se abordó la noción de cortometraje en el seno de la institucionalización del largometraje de ficción. Se efectuó un recorrido por las diversas variantes y funciones que adoptó el filme de corta duración, desde las actualidades, los noticiarios de las décadas del veinte al cincuenta, el cine científico, deteniéndose en los cortos ficcionales de variedad musical y en el cortometraje etiquetado como revista musical filmada. Se trató la incursión vanguardista en la década del treinta y el documental experimental en el ámbito de los cineclubes, además de los documentales institucionales durante la presidencia de Juan Domingo Perón. En cada uno de estos bloques se ha puesto el foco en la vinculación del cortometraje con el canon productivo y estético a nivel industrial e institucional. Como resultado, se constató una amplia homologación del filme breve con las normas tradicionales y predominantes de estilo clásico. A su vez, puede advertirse en cada caso la eficacia de la medida de corta duración: en las actualidades y en los noticiarios la brevedad permite sostener la articulación de núcleos temáticos diversos y una organización simple de la inmediatez de los hechos. En el cine científico favorece la conjugación de la función didáctica y el carácter espectacular como método de aprehensión del espectador. También el género musical cuadra a la perfección en el soporte breve. Los bajos costos y la libertad estética dada la ausencia de condicionantes comerciales, son cualidades potenciales que la vanguardia encuentra en este formato para experimentar con el montaje, la cámara y los recursos narrativos. Los documentales institucionales propagandísticos se valen de la unidad temática y la concentración estructural para influir de forma efectiva en el receptor.
Este trabajo se distingue por la perspectiva de aproximación adoptada. Las distintas modalidades filmicas recuperadas ya fueron estudiadas, pero no se han examinado desde un enfoque que centre su atención en el filme de corta duración y su productividad como medio audiovisual. La puesta en relieve de las formas que el cortometraje ha manifestado en esta gran fase de la cinematografía argentina permite comprender desde un punto de vista más complejo su injerencia y su carácter alternativo en la modernidad fílmica, al establecer continuidades y rupturas con respecto a su trayectoria anterior. El corto como vehículo de experimentación y herramienta de transformación política no surgió de la noche a la mañana. Si bien su aparición responde a un contexto cultural y social específico, caracterizado por un espíritu modernizador y una efervescencia social, ${ }^{21}$ el cortometraje descubrió sus posibilidades estructurales, estéticas y funcionales a lo largo del desarrollo de la historia del cine local. A pesar de que la gran mayoría de los ejemplos y modos analizados estuvieron muy asociados a los imperativos industriales e institucionales, el corto logró ensayar marcas de lenguaje propias y campos de acción específicos. A partir de estas experiencias fue posible la gestación de nuevas variables dentro del cortometraje. En este sentido, la relación entre tradición y modernidad en el corto argentino no vislumbra un carácter de ruptura absoluta, sino que se evidencia como un fenómeno complejo donde lo nuevo se nutre del recorrido alcanzado, aunque sea para distanciarse.

\section{Referencias}

Benet, J. V. (2008). La cultura del cine: introducción a la historia y la estética del cine. Barcelona, España: Paidós.

Cossalter, J. (2013). El orden conciliado frente a las voces disidentes. Un estudio comparado entre el cortometraje documental institucional en la Argentina del peronismo y el cortometraje documental alternativo de los años sesenta. DOCOn-line, 14, 181-210. Recuperado de: http://www.doc.ubi.pt/14/artigos_javier_cossalter.pdf

Cossalter, J. (2014). El cine experimental de cortometraje en la argentina de los años sesenta y setenta: apropiaciones y vinculaciones transnacionales. European Review of Artistic Studies, 5(4), 32-49.
21:: Ana Longoni y Mariano Mestman (2008), Oscar Terán (1991) y Claudia Gilman (2003) analizan el campo cultural argentino de los años cincuenta y sesenta a partir de estos postulados. 
Recuperado de: http://www.eras.utad.pt/docs/DEZ\%20VISUAIS\%20 2014.pdf

Cossalter, J. (2015a). Renovación estética e instrumentalización política radical. El cortometraje moderno en Argentina (1955-1976). Questión, 1(47), 309-324. Recuperado de:http://perio.unlp.edu.ar/ ojs/index.php/question/article/view/2535

Cossalter, J. (2015b). Política y transformación en el cortometraje documental argentino (1966-1976). Perspectivas de la Comunicación, 8(1), 79-100. Recuperado de:http://publicacionescienciassociales. ufro.cl/index.php/perspectivas/article/view/177/465

Cuarterolo, A. (2013). De la foto al fotograma. Relaciones entre cine y fotografía en la Argentina (1840- 1933). Montevideo, Uruguay: CdF Ediciones.

Cuarterolo, A. (2015). El cine científico en la Argentina de principios del siglo XX. Entre la educación y el espectáculo. Revista História da Educação, Dossier Imagem e cultura visual, 19(47), 51-73. doi: 10.1590/2236-3459/47763

Di Chiara, R. (1996). El cine mudo argentino. Homenaje a los 100 años de la primera exhibición cinematográfica argentina. Buenos Aires, Argentina: Edición del Autor.

España, C. (1996). El cine argentino. En La Junta de Historia y Numismática Americana y el movimiento historiográfico en la Argentina (1893-1938). Volumen II. Buenos Aires, Argentina: Academia Nacional de la Historia.

España, C. (Comp.). (2000). Cine argentino: industria y clasicismo / 1933-1956. Volumen I. Buenos Aires, Argentina: Fondo Nacional de las Artes.

Gilman, C. (2003). Entre la pluma y el fusil. Debates y dilemas del escritor revolucionario en América Latina. Buenos Aires, Argentina: Siglo XXI.

Kriger, C. (2009). Cine y peronismo. El estado en escena. Buenos Aires, Argentina: Siglo XXI.

Longoni, A., y Mestman, M. (2008). Del Di Tella a "Tucumán Arde". Vanguardia artística y política en el 68 argentino. Buenos Aires, Argentina: Eudeba.

Lusnich, A. L., y Piedras, P. (Eds.). (2009). Una historia del cine político y social en Argentina (1896-1969). Buenos Aires, Argentina: Nueva Librería.

Marrone, I. (2003). Imágenes del mundo histórico. Identidades y representaciones en el noticiero y el documental en el cine mudo argentino. Buenos Aires, Argentina: Prometeo.

Marrone, I., y Moyano Walker, M. (Eds.). (2006). Persiguiendo imágenes. El noticiario argentino, la memoria y la historia (19301960). Buenos Aires, Argentina: Del Puerto.
Mell, N. (2011). La cinematografía argentina de cortometraje en el período mudo. En Actas II Congreso Internacional de la Asociación Argentina de Estudios de Cine y Audiovisual. Buenos Aires, Argentina: AsAECA - Asociación Argentina de Estudios de Cine y Audiovisual. E-Book. Recuperado de: http://asaeca. org/actas-de-congresos-asaeca/

Oubiña, D. (2009). La piel del mundo. Horacio Coppola y el cine. En Horacio Coppola. Los viajes (pp. 191-210). Buenos Aires, Argentina: Galería Jorge Mara-La Ruche.

Peña, F. M. (2012). Cien años de cine argentino. Buenos Aires, Argentina: Biblos-Fundación OSDE.

Terán, O. (1991). Nuestros años sesentas. Buenos Aires, Argentina: Puntosur.

Weinrichter, A. (2004). Desvíos de lo real. El cine de no ficción. Madrid, España: T\&tB Editores.

Filmes:

Bortnowski, T. (Productor). (1949). Para todos los hombres del mundo [Cortometraje]. Argentina: Noticiero Bonaerense-Emelco-Sucesos Argentinos.

Cardini, E. (Productor \& Director). (1902). Escenas callejeras [Cortometraje]. Argentina: Independiente.

Coppola, H. (Productor \& Director). (1934). Un Quai de la Seine [Cortometraje]. Francia: Independiente.

Coppola, H. (Productor \& Director). (1935). A Sunday in Hampstead Heath [Cortometraje]. Inglaterra: Independiente.

Coppola, H. (Productor \&t Director). (1936). Así nació el obelisco [Cortometraje]. Argentina: Independiente.

Coppola, H. (Productor \&t Director). (1937). Vestir al bebé [Cortometraje]. Argentina: Dirección de Maternidad e Infancia.

Coppola, H. (Productor \& Director). (1943). Do de pecho [Cortometraje]. Argentina: Dirección de Maternidad e Infancia.

Coppola, H. (Productor), Coppola, H., Auerbach, W. (Directores). (1933). Traum [Cortometraje]. Alemania: Independiente.

de la Cárcova, E. (Productor \& Director). (1937). Luz y sombra [Cortometraje]. Argentina: Cine Club Argentino.

Gallo, M. (Productor \& Director). (1909). El fusilamiento de Dorrego [Cortometraje]. Argentina: Estudio Cinematográfico Mario Gallo.

Gallo, M. (Productor \&t Director). (1909). La creación del himno [Cortometraje]. Argentina: Estudio Cinematográfico Mario Gallo. 
Gallo, M. (Productor \&t Director). (1909). La revolución de mayo [Cortometraje]. Argentina: Estudio Cinematográfico Mario Gallo. Gallo, M. (Productor \& Director). (1912). Tierra baja [Película]. Argentina: Estudio Cinematográfico Mario Gallo.

Gallo, M. (Productor \&t Director). (1921). La sifilis y sus consecuencias [Cortometraje]. Argentina: Estudio Cinematográfico Mario Gallo-Ministerio de Guerra.

Glücksmann, M. (Productor), García Velloso, E. (Director). (1914). Amalia [Película]. Argentina: Cinematografía Max Glücksmann.

Guidi, R. (Productor), Iribarren, E. (Director). (1929). Mosaico criollo [Cortometraje]. Argentina: Ariel.

Lepage, H. (Productor), Py, E. (Director). (1897). La bandera argentina [Cortometraje]. Argentina: Casa Lepage.

Lepage, H. (Productor), Py, E. (Director). (1899-1900). Operaciones del Doctor Posadas [Cortometraje]. Argentina: Casa Lepage.

Lepage, H. (Productor), Py, E. (Director). (1900). Visita del Dr. Campos Salles a Buenos Aires [Cortometraje]. Argentina: Casa Lepage.

Lowe, K. (Productor). (1948). Rumbo a la Argentina [Cortometraje]. Argentina: Emelco.

Martínez de La Pera, E., Gunche, E. (Productores \& Directores). (1922). Instituto Modelo de Clínica Médica [Cortometraje]. Argentina: Establecimiento Cinematográfico Martínez y Gunche.

Martínez de La Pera, E., Gunche, E. (Productores \& Directores). (1920). La mosca y sus peligros [Mediometraje]. Argentina: Establecimiento Cinematográfico Martínez y Gunche.

Méndez Delfino, J. (Productor \& Director). (1933). Caperucita roja [Cortometraje]. Argentina: Cine Club Argentino.

Mentasti, A. (Productor), Borcosque, C. (Director). (1953). Su obra de amor [Cortometraje]. Argentina: Argentina Sono Film.

Mentasti, A., Moglia Barth, L. (Productores), Moglia Barth, L. (Director). (1933). iTango! [Película]. Argentina: Argentina Sono Film.

Quadro, P. (Productor \& Director). (1920). Técnica general para las amputaciones cineplásticas, nuevo procedimiento del Dr. Guillermo Bosch Arana [Cortometraje]. Argentina: F.I.F.A.

Robertié, R., Barrios Barón, C. (Productores \&t Directores). (1950). La gesta inmortal [Cortometraje]. Argentina: Cine Club Argentino.

Scaglione, L. (Productor \& Director). (1925). Operaciones del Instituto de Clínica Quirúrgica [Cortometraje]. Argentina: Colón Film.

Valle, F. (Productor \& Director). (1926). El azúcar [Cortometraje]. Argentina-Estados Unidos: Cinematografía Valle-Kodak.

Valle, F. (Productor \& Director). (ca. 1920). Buenos Aires, la magnífica [Cortometraje]. Argentina: Cinematografía Valle-YPF.

Valle, F. (Productor \&t Director). (ca. 1920). Córdoba y sus sierras
[Cortometraje]. Argentina: Cinematografia Valle-YPF.

Valle, F. (Productor \& Director). (ca. 1920). Hacia el Iguazú [Cortometraje]. Argentina: Cinematografía Valle-YPF.

Valle, F. (Productor \& Director). (ca. 1920). La Pampa generosa [Cortometraje]. Argentina: Cinematografía Valle-YPF.

Valle, F. (Productor \& Director). (ca. 1920). La región de los hielos eternos [Cortometraje]. Argentina: Cinematografía Valle-YPF.

Valle, F. (Productor \&t Director). (ca. 1920). Nahuel Huapi [Cortometraje]. Argentina: Cinematografía Valle-YPF.

Valle, F. (Productor \&t Director). (ca. 1920). Norte argentino: Salta, Jujuy y parte de Tucumán [Cortometraje]. Argentina: Cinematografía Valle-YPF.

Valle, F. (Productor \& Director). (ca. 1920). Por tierras cuyanas [Cortometraje]. Argentina: Cinematografía Valle-YPF.

Valle, F. (Productor \& Director). (ca. 1920). Por tierras de Santa Fe [Cortometraje]. Argentina: Cinematografía Valle-YPF.

Valle, F. (Productor), Morera, E. (Director). (1930). Añoranzas [Cortometraje]. Argentina: Cinematografía Valle.

Valle, F. (Productor), Morera, E. (Director). (1930). Canchero [Cortometraje]. Argentina: Cinematografía Valle.

Valle, F. (Productor), Morera, E. (Director). (1930). El carretero [Cortometraje]. Argentina: Cinematografía Valle.

Valle, F. (Productor), Morera, E. (Director). (1930). El quinielero [Cortometraje]. Argentina: Cinematografía Valle.

Valle, F. (Productor), Morera, E. (Director). (1930). Enfundá la mandolina [Cortometraje]. Argentina: Cinematografía Valle.

Valle, F. (Productor), Morera, E. (Director). (1930). Mano a Mano [Cortometraje]. Argentina: Cinematografía Valle.

Valle, F. (Productor), Morera, E. (Director). (1930). Padrino Pelao [Cortometraje]. Argentina: Cinematografía Valle.

Valle, F. (Productor), Morera, E. (Director). (1930). Rosas de otoño [Cortometraje]. Argentina: Cinematografía Valle.

Valle, F. (Productor), Morera, E. (Director). (1930). Tengo miedo [Cortometraje]. Argentina: Cinematografía Valle.

Valle, F. (Productor), Morera, E. (Director). (1930). Viejo smoking [Cortometraje]. Argentina: Cinematografía Valle.

Valle, F. (Productor), Morera, E. (Director). (1930). Yira yira [Cortometraje]. Argentina: Cinematografía Valle.

Werner, E. (Productor \& Director). (1937). Nahuel Huapi y su región [Cortometraje]. Argentina: Cine Club Argentino.

Wilson, A. Z. (Productor), Ferreyra, J. A. (Director). (1931). Muñequitas porteñas [Película]. Argentina: Patagonia Film. 